BrazilianJournal

of Chemical

ISSN 0104-6632

Engineering

\title{
THE THERMAL DECOMPOSITION OF MONOHYDRATED AMMONIUM OXOTRIS(OXALATE)NIOBATE
}

\author{
F. F. P. Medeiros ${ }^{1}$, M. F. V. Moura ${ }^{2}$, A. G. P da Silva ${ }^{3}$,C. P. Souza ${ }^{1}$, \\ K. K. P. Gomes ${ }^{1}$ and U. U. Gomes ${ }^{2}$ \\ ${ }^{1,2}$ Universidade Federal Rio Grande do Norte, CT, DEQ ${ }^{1}$ / CCET/DFTE ${ }^{2}$, Campus Universitário, \\ Phone: +(55) (84) 3215-3769/Fax: 3215-3770, CEP 59072-970, Natal - RN, Brazil. \\ E-mail: carlson@ufrnet.br \\ ${ }^{3}$ Universidade Estadual do Norte Fluminense, LAMAV, \\ CEP: 28015-620, Campos - RJ, Brazil.
}

(Received: February 13, 2003 ; Accepted: July 17, 2006)

\begin{abstract}
The thermal decomposition in argon of the monohydrated ammonium tris(oxalate)niobate, $\left(\mathrm{NH}_{4}\right)_{3} \mathrm{NbO}\left(\mathrm{C}_{2} \mathrm{O}_{4}\right)_{3} \cdot \mathrm{H}_{2} \mathrm{O}$, has been studied by TG/DTG, DTA, DSC, IR absorption and XRD. The material decomposes stepwise by the release of $\mathrm{CO}, \mathrm{CO}_{2}, \mathrm{NH}_{3}$ and water. The atomic structure of the complex initially becomes amorphous and then crystallizes twice in the form of orthorhombic and monoclinic niobium pentoxide. Keywords: Thermal decomposition; Thermal analysis; Infrared; Niobium complex.
\end{abstract}

\section{INTRODUCTION}

The oxalate ion is a bidentate, chelate ligand that can form complexes with niobium (Cotton and Wilkinson, 1982). The niobium complexes are named according to the number of oxalate groups that bonds to the niobium ion. These complexes can be obtained with the dissolution of hydrated niobium oxide in an aqueous oxalic acid solution, followed by a treatment with a suitable salt. The first niobium complexes were obtained from the alkali metals and were named mono, bus and tris(oxalate) niobate (Khrishnamurty and Harris, 1961).

Mathern et al. (1969), determined the structure of monohydrated ammonium oxotris(oxalate) niobate. Its formula is $\left(\mathrm{NH}_{4}\right)_{3} \mathrm{NbO}\left(\mathrm{C}_{2} \mathrm{O}_{4}\right)_{3} \cdot \mathrm{H}_{2} \mathrm{O}$. Niobium is seven coordinated (to three oxalate groups and to oxygen), forming a pentagonal bipyramid.

Monohydrated ammonium oxotris(oxalate)niobate and monohydrated ammonium oxotris(oxalate)tantalate have been used for synthesizing $\mathrm{NbC}$ and $\mathrm{TaC}$, respectively, at low temperatures (between $950^{\circ} \mathrm{C}$ and $1050^{\circ} \mathrm{C}$ ) through a gas-solid reaction (Medeiros et al., 2002; Ciaravino et al., 2002). The gaseous reactant is a mixture of $\mathrm{CH}_{4}$ and $\mathrm{H}_{2}$. Methane is the carbon source. Hydrogen avoids the precipitation of free carbon caused by the cracking of $\mathrm{CH}_{4}$ (Clar, 1964) and acts as a reducer. The solid reactant is the $\mathrm{Nb}$ or Ta complex. The cracks and pores that appear during the thermal decomposition of the complexes increase its specific surface area and its reactivity (Medeiros et. al., 2002) The conventional method utilized for producing these carbides uses temperatures as high as $1800^{\circ} \mathrm{C}$ (Toth, 1971; Storms, 1971).

In the present paper, the thermal decomposition of monohydrated ammonium oxotris(oxalate)niobate that is studied. Its composition is determined. The gases released and the crystalline changes that occur during the process are reported.

*To whom correspondence should be addressed 


\section{EXPERIMENTAL}

\section{Synthesis of the Complex}

Niobium pentoxide $\left(\mathrm{Nb}_{2} \mathrm{O}_{5}\right)$ is mixed with sodium hydrogen sulfate $\left(\mathrm{KHSO}_{4}\right)$ at a 1:7 weight ratio. The mixture is heated to melting in a platinum crucible. After cooling, the material is crushed and washed in a $1: 1 \mathrm{HCl}$ aqueous solution during 24 hours to remove impurities. Subsequently, the material is filtered and washed with hot water. Hydrated niobium oxide is formed. This oxide is added to a solution of oxalic acid and ammonium oxalate (1:1 molar ratio) and the solution is slowly evaporated. The complex precipitates and is dried at $70^{\circ} \mathrm{C}$ for 24 hours. The granulated material is further powdered in a mortar.

\section{Decomposition Study}

The thermal decomposition was studied by means of a combination of techniques described as follows:

- Thermogravimetry (TG/DTG) (Shimadzu TGA50 thermobalance) in an argon atmosphere. Two temperature programs were used. In the first case, the temperature rises continuously from room temperature (RT) to $900^{\circ} \mathrm{C}$ at a rate of $5^{\circ} \mathrm{C} / \mathrm{min}$. In the second case, the temperature range is $\mathrm{RT}-630^{\circ} \mathrm{C}$, the heating rate is $5^{\circ} \mathrm{C} / \mathrm{min}$. and there are isotherms of 20 minutes at $140^{\circ}$, $200^{\circ}, 250^{\circ}$ and $620^{\circ} \mathrm{C}$.
- Differential thermal analysis (DTA) (Netzsch STA 409C) in argon in the temperature range RT $950^{\circ} \mathrm{C}$ and at a heating rate of $5^{\circ} \mathrm{C} / \mathrm{min}$.

- Differential scanning calorimetry (DSC) (DSC-50 Shimadzu) in argon in the temperature range RT $600^{\circ} \mathrm{C}$ and at a heating rate of $2^{\circ} \mathrm{C} / \mathrm{min}$.

- $\mathrm{C}, \mathrm{N}$ and $\mathrm{H}$ quantitative elemental analysis of the niobium complex (Perkin Elmer CHN 2400).

- X-Ray diffraction (XRD) (Siemens diffractometer, $\mathrm{Cu} \mathrm{K \alpha}$ radiation) of $\mathrm{Nb}_{2} \mathrm{O}_{5}$, the niobium complex and the residue of the niobium complex decomposed at $200^{\circ}, 400^{\circ}, 700^{\circ}$ and $950^{\circ} \mathrm{C}$.

- Infrared spectroscopy (Perkin Elmer FTIR 16PC) using $\mathrm{KBr}$ tablets of $\mathrm{Nb}_{2} \mathrm{O}_{5}$, the niobium complex and its residue after decomposition at $140^{\circ}, 200^{\circ}$, $250^{\circ}, 400^{\circ}, 630^{\circ}, 700^{\circ}$ and $950^{\circ} \mathrm{C}$.

- Detection of $\mathrm{NH}_{3}$ and $\mathrm{CO}_{2}$ released during decomposition by traps installed according to Fig. 1.

\section{RESULTS AND DISCUSSION}

\section{Thermal Analysis}

Figures 2-5 show the results of TG/DTG, DTA and DSC of the decomposing niobium complex. The TG/DTG curves (Figs 2-3) show four temperature range in which the sample loses mass. The DTA and DSC curves (Figs. 4-5) show that each mass loss event corresponds to a peak of DTA and DSC. Table 1 summarizes the results shown in Figs. 2-5.

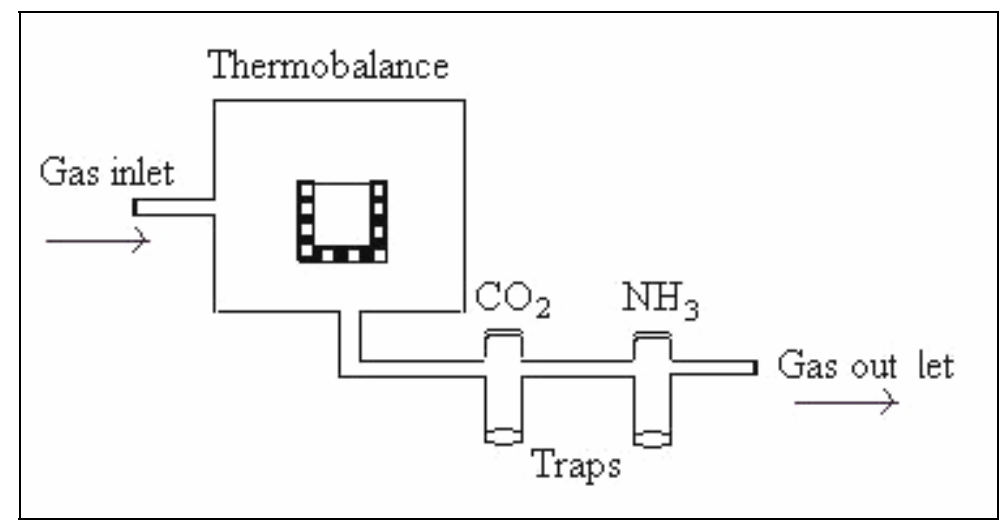

Figure 1: Outline of the apparatus utilized to detect $\mathrm{CO}_{2}$ and $\mathrm{NH}_{3}$ that released during the thermal decomposition. 


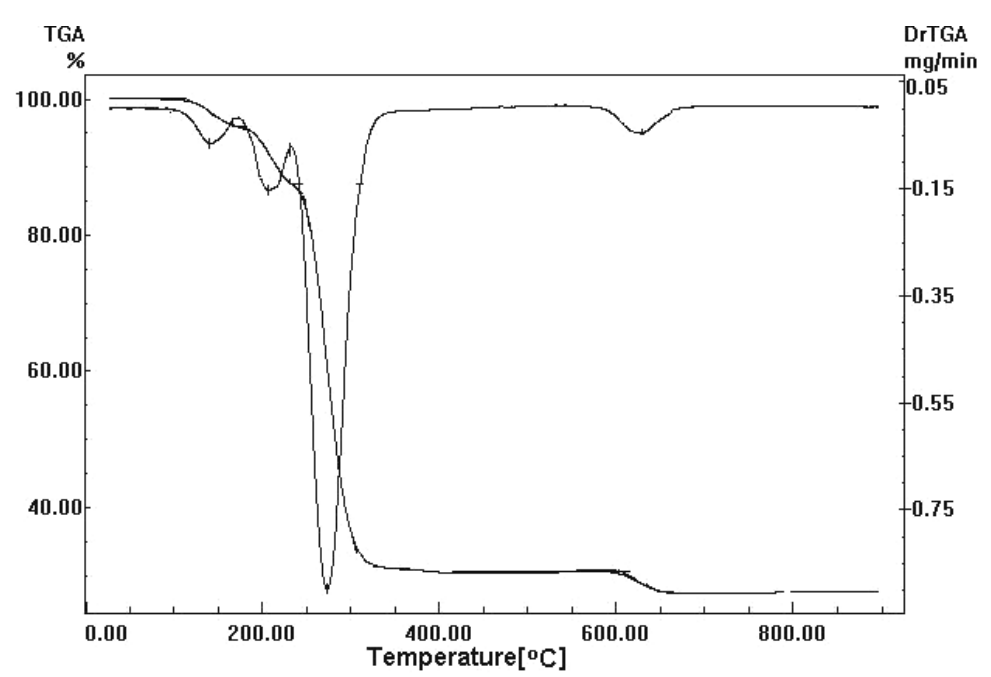

Figure 2: TG/DTG curves of the thermal decomposition in argon of the niobium complex. Heating rate: $5^{\circ} \mathrm{C} / \mathrm{min}$.

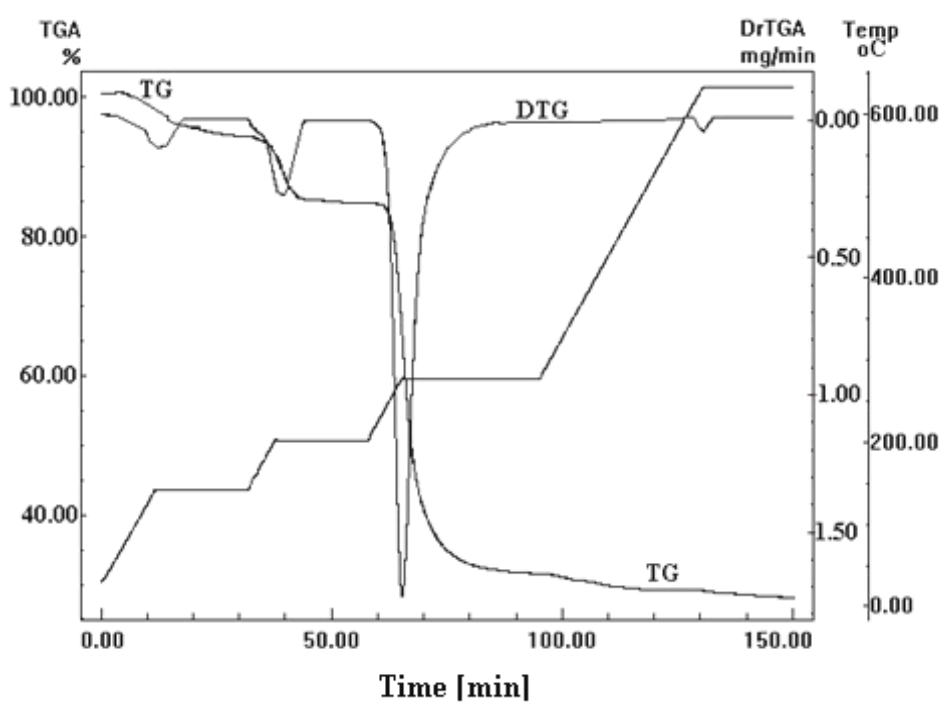

Figure 3: TG/DTG curves of the thermal decomposition in argon of the niobium complex. Temperature increases stepwise.

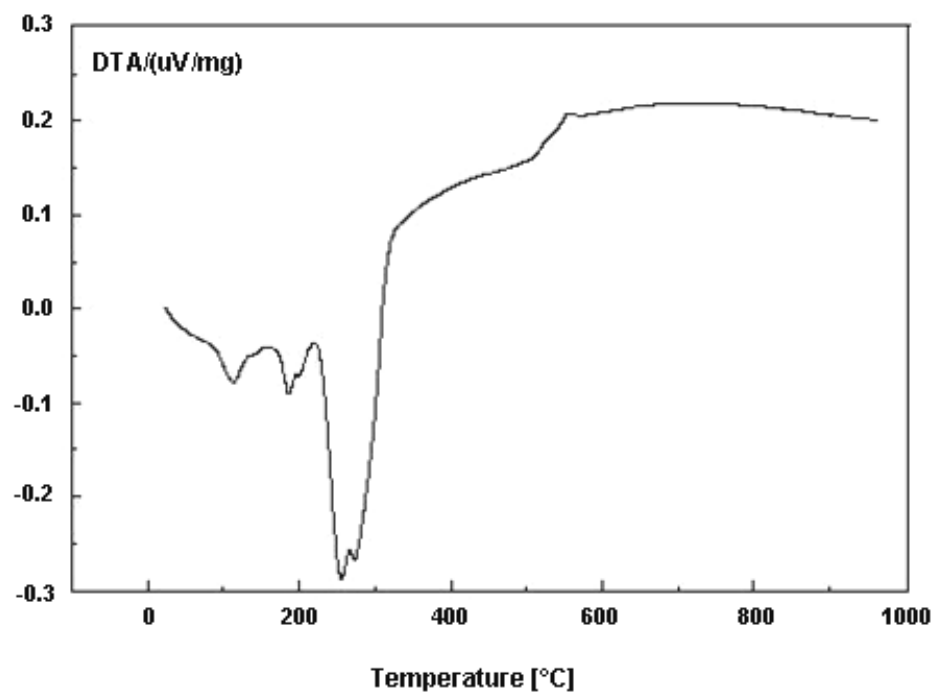

Figure 4: DTA curve of the thermal decomposition in argon of the niobium complex. Heating rate $5^{\circ} \mathrm{C} / \mathrm{min}$. 


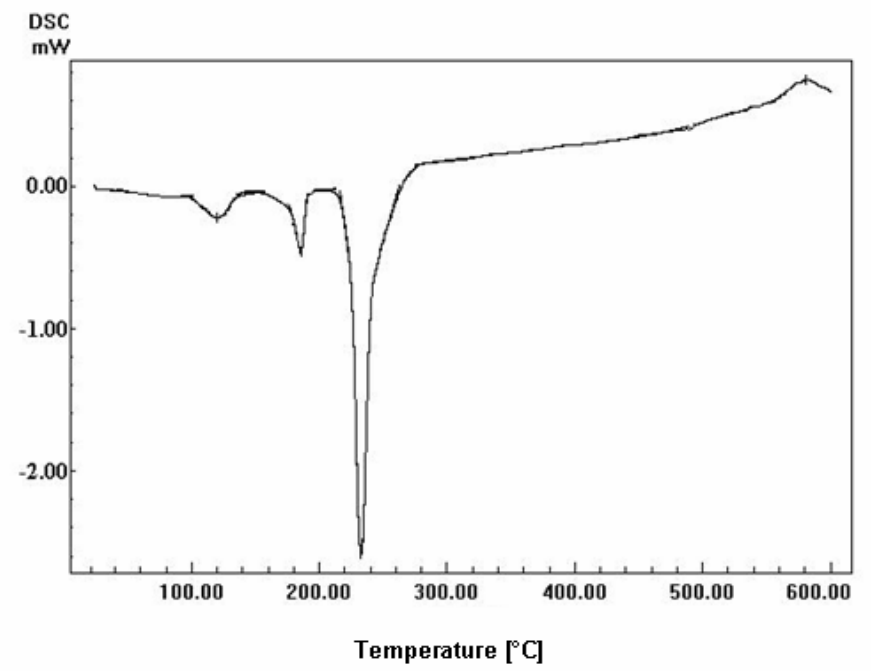

Figure 5: DSC curve of the thermal decomposition in argon of the niobium complex. Heating rate: $2^{\circ} \mathrm{C} / \mathrm{min}$.

Table 1: Summary of the TG/DTG, DTA and DSC techniques for the decomposition of the niobium complex.

\begin{tabular}{|c|c|c|c|c|c|}
\hline \multirow{2}{*}{ Technique } & \multirow{2}{*}{$\begin{array}{c}\text { Characteristics of } \\
\text { the Event }\end{array}$} & \multicolumn{4}{|c|}{ Decomposition Step } \\
\hline & & 1 & 2 & 3 & 4 \\
\hline \multirow{4}{*}{ TG/DTG } & Initial Temperature & $98^{\circ} \mathrm{C}$ & $181^{\circ} \mathrm{C}$ & $244^{\circ} \mathrm{C}$ & $600^{\circ} \mathrm{C}$ \\
\hline & Final Temperature & $145^{\circ} \mathrm{C}$ & $223^{\circ} \mathrm{C}$ & $301^{\circ} \mathrm{C}$ & $630^{\circ} \mathrm{C}$ \\
\hline & $\begin{array}{l}\text { Temperature of } \\
\text { Max. Intensity }\end{array}$ & $135^{\circ} \mathrm{C}$ & $207^{\circ} \mathrm{C}$ & $261^{\circ} \mathrm{C}$ & $617^{\circ} \mathrm{C}$ \\
\hline & Mass Variation \% & 4.3 & 8.4 & 57.30 & 3.02 \\
\hline DTA & $\begin{array}{l}\text { Characteristic of the } \\
\text { Peak }\end{array}$ & endo & endo & endo & exo \\
\hline \multirow{4}{*}{$\mathrm{DSC}$} & Initial Temperature & $98^{\circ} \mathrm{C}$ & $172^{\circ} \mathrm{C}$ & $217^{\circ} \mathrm{C}$ & $533^{\circ} \mathrm{C}$ \\
\hline & Final Temperature & $137^{\circ} \mathrm{C}$ & $191^{\circ} \mathrm{C}$ & $268^{\circ} \mathrm{C}$ & $600^{\circ} \mathrm{C}$ \\
\hline & $\begin{array}{l}\text { Temperature of } \\
\text { Max. Intensity }\end{array}$ & $120^{\circ} \mathrm{C}$ & $186^{\circ} \mathrm{C}$ & $233^{\circ} \mathrm{C}$ & $580^{\circ} \mathrm{C}$ \\
\hline & $\begin{array}{l}\text { Variation Enthalpy } \\
\text { in }(\mathrm{KJ} / \mathrm{mol})\end{array}$ & 42.02 & 47.70 & 18.15 & -- \\
\hline
\end{tabular}

\section{Release of Gas Phase}

The releasing of both $\mathrm{CO}_{2}$ and $\mathrm{NH}_{3}$ was detected by the traps in the temperature intervals corresponding to the second and third mass loss events (Table 1), related to endothermal peaks on the DTA curve. Production of $\mathrm{CO}_{2}$ is also detected around $600^{\circ} \mathrm{C}$, corresponding to the forth event (an exothermal DTA peak). Marta et al. (1983) related the releasing of this gas to the desorption of some of the $\mathrm{CO}_{2}$ produced at a lower temperature and adsorbed on the surface of the material. But desorption events are endothermic. Other possibilities for this $\mathrm{CO}_{2}$ release are: (1) the oxidation of pyrolytically formed carbon by traces of oxygen in the atmosphere and (2) an event related to the decomposition of the niobium complex.

Figure 6 shows the IR spectra of the niobium complex and its residues after decomposition at several temperatures. The spectrum of the initial $\mathrm{Nb}_{2} \mathrm{O}_{5}$ is also shown. Table 2 summarizes the results and relates the absorption bands to the vibration types. 


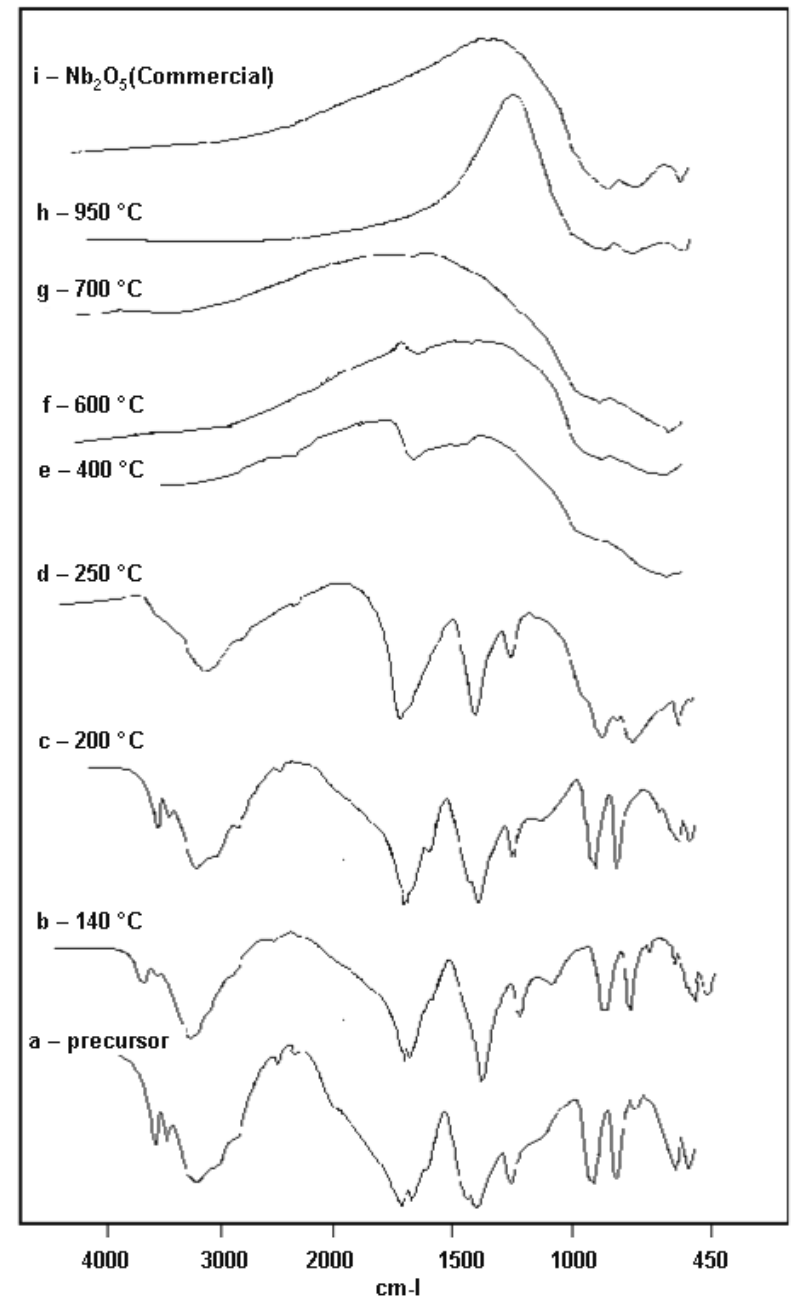

Figure 6: IR absorption spectra of the niobium complex (precursor), the complex decomposed at $140^{\circ}, 200^{\circ}$, $250^{\circ}, 400^{\circ}, 600^{\circ}, 700^{\circ}$ and $950^{\circ} \mathrm{C}$ and the niobium oxide used as raw material.

Table 2: Absorption bands of the niobium complex and its residue after decomposition at several temperatures. The types of vibration related to the respective bands are shown.

\begin{tabular}{|c|c|c|c|c|c|c|c|c|}
\hline $\begin{array}{l}\text { Decomposition } \\
\text { Temperature }\end{array}$ & $\begin{array}{l}\text { Niobium } \\
\text { complex }\end{array}$ & $140^{\circ} \mathrm{C}$ & $200^{\circ} \mathrm{C}$ & $250^{\circ} \mathrm{C}$ & $400^{\circ} \mathrm{C}$ & $630^{\circ} \mathrm{C}$ & $700^{\circ} \mathrm{C}$ & $950^{\circ} \mathrm{C}$ \\
\hline Type of Vibration & \multicolumn{8}{|c|}{ Absorption Bands $\left(\mathrm{cm}^{-1}\right)$} \\
\hline \multirow[t]{2}{*}{$\mathrm{N}-\mathrm{H}$} & 3539 & 3539 & 3538 & -- & -- & -- & -- & -- \\
\hline & 3442 & 3442 & 3442 & 2126 & & & & \\
\hline $\mathrm{H}-\mathrm{O}$ & 3212 & 3212 & 3199 & 3126 & -- & -- & -- & -- \\
\hline \multirow{2}{*}{$v(\mathrm{C}=\mathrm{O})$} & 1714 & 1714 & 1711 & 1722 & 1621 & 1621 & $\ldots$ & $-{ }_{-}$ \\
\hline & 1683 & 1683 & 1683 & 1722 & 1021 & 1021 & -- & -- \\
\hline$v(\mathrm{C}=\mathrm{O}), v(\mathrm{C}-\mathrm{C})$ & 1387 & 1387 & 1389 & 1396 & -- & -- & -- & -- \\
\hline$v(\mathrm{C}-\mathrm{O}), \quad \delta(\mathrm{O}-\mathrm{C}=\mathrm{C})$ & 1241 & 1241 & 1239 & 1243 & -- & -- & -- & -- \\
\hline$v(\mathrm{Nb}=\mathrm{O})$ & 889 & 889 & 886 & -- & -- & -- & -- & -- \\
\hline$\delta(\mathrm{O}-\mathrm{C}=\mathrm{O})$ & 793 & 793 & 790 & 720 & -- & -- & -- & -- \\
\hline$v(\mathrm{C}-\mathrm{C}), \delta(\mathrm{O}-\mathrm{C}=\mathrm{O})$ & 538 & 538 & 534 & -- & -- & -- & -- & -- \\
\hline$\delta(\mathrm{O}-\mathrm{C}=\mathrm{O})+, v(\mathrm{Nb}-\mathrm{O})$ & 479 & 479 & 479 & 479 & -- & -- & -- & -- \\
\hline \multirow{2}{*}{$v(\mathrm{Nb}-\mathrm{O})$} & \multirow[b]{2}{*}{--} & \multirow[b]{2}{*}{--} & \multirow[b]{2}{*}{--} & \multirow[b]{2}{*}{--} & \multirow[b]{2}{*}{540} & \multirow[b]{2}{*}{540} & \multirow{2}{*}{$\begin{array}{l}540 \\
807\end{array}$} & 826 \\
\hline & & & & & & & & 691 \\
\hline
\end{tabular}


It can be seen that the absorption band related to $\mathrm{N}$ $\mathrm{H}$ is detected only in residues decomposed up to $200^{\circ} \mathrm{C}$. This corresponds to the release of the oxalate ions contained in the complex through the releasing of $\mathrm{NH}_{3}$ up to $250^{\circ} \mathrm{C}$. The absorption band related to the hydration water (H-O vibration) is not detected in the residue after decomposition at $400^{\circ} \mathrm{C}$. The spectra in Fig. 6 shows that the absorption bands related to the hydration water change significantly above $200^{\circ} \mathrm{C}$ and vanishes in the residue of decomposition at $400^{\circ}$. This means that the water is released mainly in the third mass loss event, in the range from $240^{\circ}$ to $300^{\circ} \mathrm{C}$.

The absorption bands corresponding to the vibrations $\mathrm{C}=\mathrm{O}, \mathrm{C}=\mathrm{C}, \mathrm{C}-\mathrm{C}, \mathrm{O}-\mathrm{C}=\mathrm{C}$ and $\mathrm{O}-\mathrm{C}=\mathrm{O}$ are related to the oxalate ion. Some other bands are related to the bond between this ion and the niobium atom (Mathern et al., 1969) (Marta et al., 1983; 1979). Most of these bands are not present in the residues of decomposition above $250^{\circ} \mathrm{C}$. Combining the results of the IR spectra, TG/DTG and those of the detection of released gases, one concludes that the niobium complex releases the oxalate ions stepwise in the range from $170^{\circ}$ to $300^{\circ} \mathrm{C} . \mathrm{CO}_{2}$ and $\mathrm{CO}$ are released. Although only $\mathrm{CO}_{2}$ was detected (CO was not analyzed), the evolution of $\mathrm{CO}$ and $\mathrm{CO}_{2}$ is common in the decomposition of oxalates.

Concerning the evolution of $\mathrm{CO}_{2}$ at around $630^{\circ} \mathrm{C}$, corresponding to the fourth mass loss event detected by the TG/DTG analysis, the IR spectra of the niobium complex that decomposed at $400^{\circ}$ and $600^{\circ} \mathrm{C}$ show a band corresponding to a $\mathrm{C}=\mathrm{O}$ bond, but a band related to the bond between the oxalate ion and $\mathrm{Nb}$ was not detected. This means that the $\mathrm{C}=\mathrm{O}$ bond is not related to the bond between $\mathrm{Nb}$ and the oxalate ion. This result definitively shows that releasing of $\mathrm{CO}_{2}$ at $630^{\circ} \mathrm{C}$ is not related to the decomposition of the material.

\section{Crystal Structure}

Figure 7 shows the XRD graphs of the niobium complex, its residues after decomposition at several temperatures and the niobium oxide used as raw material. Negligible differences are seen in the patterns of the niobium complex and its residue after decomposition at $200^{\circ} \mathrm{C}$, but the complex that decomposed at $400^{\circ} \mathrm{C}$ is amorphous, as indicated by the diffraction pattern. The release of $\mathrm{CO}_{2}$ and $\mathrm{NH}_{3}$ that occurred in the second mass loss step $\left(180^{\circ}\right.$. $220^{\circ} \mathrm{C}$ ) does not disturb the crystal structure of the niobium complex, but the massive release of $\mathrm{NH}_{3}$, $\mathrm{CO}_{2}$ and the hydration water does transform the material into amorphous solids.

The exothermic peak at $600^{\circ} \mathrm{C}$ in the DTA analysis could be related to crystallization of the material and not to the release of $\mathrm{CO}_{2}$ as mentioned previous. The residue of the niobium complex decomposed at $700^{\circ} \mathrm{C}$ is crystalline, corresponding to an orthorhombic structure of $\mathrm{Nb}_{2} \mathrm{O}_{5}$ (JCPDS card No. 30-0873). This crystallization process could occur or start at $600^{\circ} \mathrm{C}$. The orthorhombic structure is transformed into amonoclinic structure between $700^{\circ}$ and $950^{\circ} \mathrm{C}$ because the residue of the decomposition at $950^{\circ} \mathrm{C}$ has another crystal structure (JCPDS card No. 37-1468). This is the same structure as that of the $\mathrm{Nb}_{2} \mathrm{O}_{5}$ used as raw material, but it is not as well crystallized.

\section{Elemental Analysis}

Nitrogen, hydrogen and carbon in the niobium complex were quantitatively analyzed. Niobium was indirectly analyzed. The residual mass of the niobium complex after calcination in air at a high temperature was measured and the $\mathrm{Nb}$ content was calculated, considering that the calcination product is $\mathrm{Nb}_{2} \mathrm{O}_{5}$. The water content is determined by the mass balance. The results are shown in Table 3, together with a simulation in which the niobium complex formula is assumed to be $\left(\mathrm{NH}_{4}\right)_{3} \mathrm{NbO}\left(\mathrm{C}_{2} \mathrm{O}_{4}\right)_{3} \cdot \mathrm{H}_{2} \mathrm{O}$. The results of the measurements and the simulation are in good agreement.

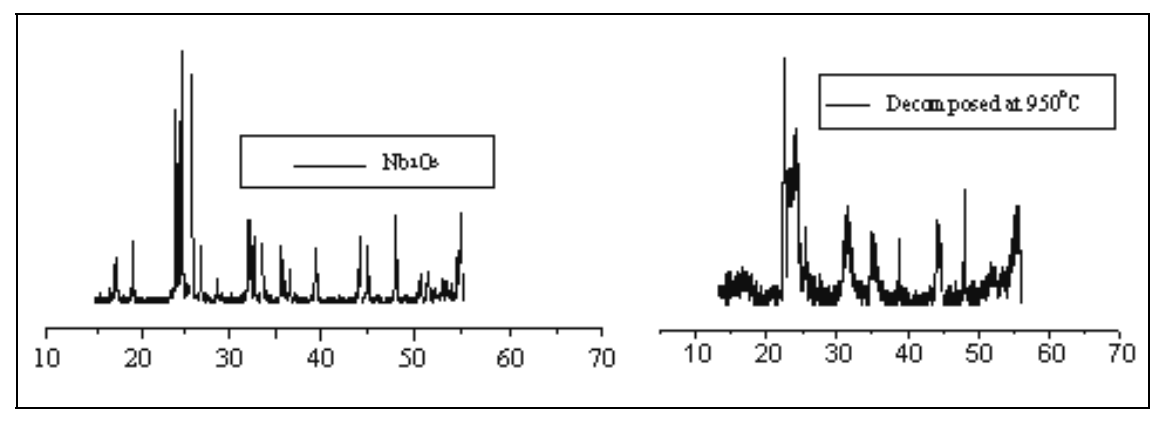




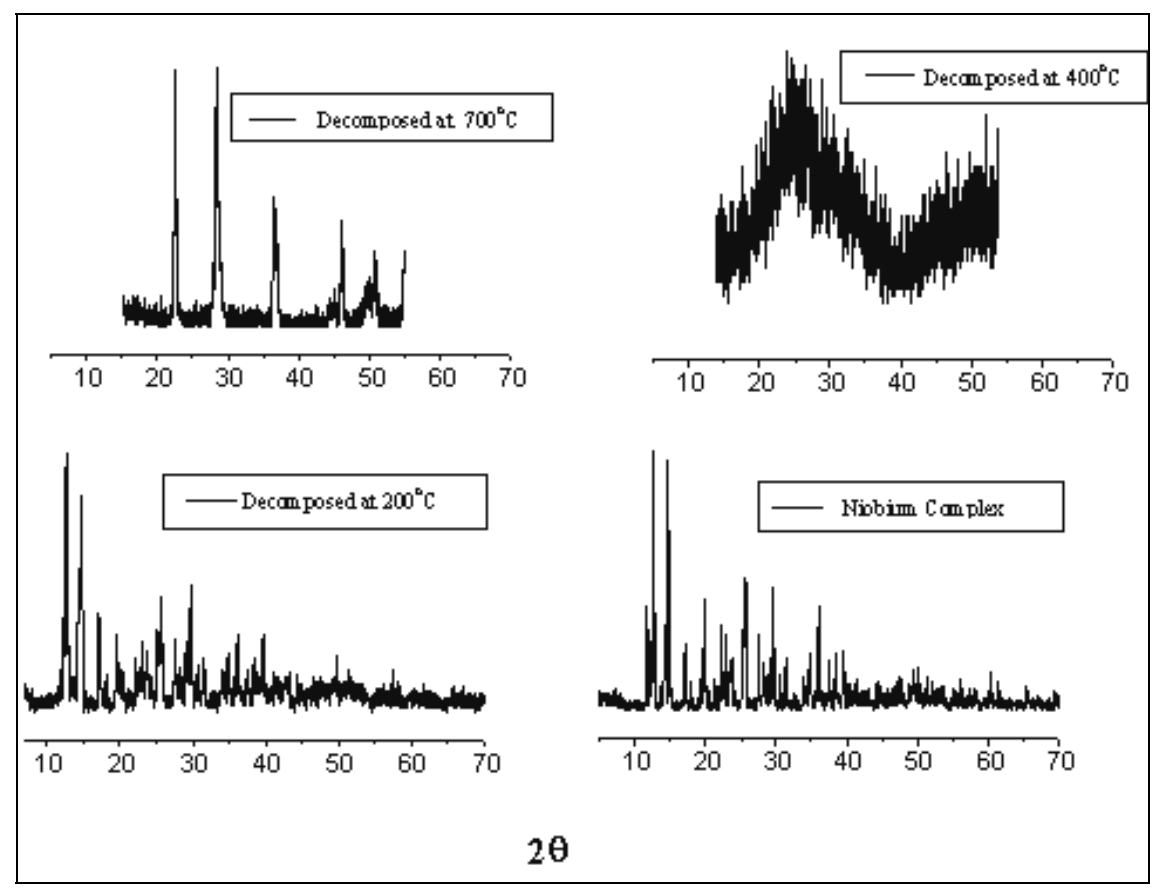

Figure 7: XRD patterns of the niobium complex (precursor), the complex decomposed at $200^{\circ}, 400^{\circ}, 700^{\circ}$ and $950^{\circ} \mathrm{C}$ and the niobium oxide used as raw material.

Table 3: Quantitative analysis of $\mathrm{Nb}, \mathrm{C}, \mathrm{N}, \mathrm{H}$ and $\mathrm{H}_{2} \mathrm{O}$ in the niobium complex and simulation based on the formula $\left(\mathrm{NH}_{4}\right)_{3} \mathrm{NbO}\left(\mathrm{C}_{2} \mathrm{O}_{4}\right)_{3} \cdot \mathrm{H}_{2} \mathrm{O}$.

\begin{tabular}{|l|c|c|c|c|c|}
\hline $\begin{array}{l}\text { Quantities } \\
\text { (weight \%) }\end{array}$ & Nb & C & N & H & $\mathbf{H}_{2} \mathbf{O}$ \\
\hline Measurement & 19.4 & 16.2 & 9.4 & 3.2 & 4.0 \\
Simulation & 19.3 & 16.6 & 9.7 & 3.2 & 4.0 \\
\hline
\end{tabular}

\section{CONCLUSIONS}

During heating, the complex monohydrated ammonium oxotris(oxalatE)niobate $\left[\left(\mathrm{NH}_{4}\right)_{3} \mathrm{NbO}\left(\mathrm{C}_{2} \mathrm{O}_{4}\right)_{3} \cdot \mathrm{H}_{2} \mathrm{O}\right]$ decomposes, releasing stepwise the oxalate ions, $\mathrm{NH}_{4}{ }^{+}$and the hydration water in the form of $\mathrm{CO}_{2}$ and $\mathrm{CO}, \mathrm{NH}_{3}$ and water vapor. Transformations also occur in the atomic structure of the material.

From $98^{\circ}$ to $145^{\circ} \mathrm{C}$, the humidity evaporates. In the range from $180^{\circ}$ to $220^{\circ} \mathrm{C}$, there is releasing of $\mathrm{NH}_{3}$ and $\mathrm{CO}_{2}$, corresponding to the partial release of the $\mathrm{NH}_{4}^{+}$and oxalate ions. The crystal structure of the niobium complex is not altered up to this temperature. Between $240^{\circ}$ and $300^{\circ} \mathrm{C}$, there is an intense loss of mass, corresponding to the evolution of $\mathrm{NH}_{3}, \mathrm{CO}_{2}, \mathrm{CO}$ and the hydration water. The crystal structure collapses and becomes amorphous. All $\mathrm{NH}_{4}{ }^{+}$ions and the hydration water are released.

At around $600^{\circ}$, there is an evolution of the residual carbon in the form of $\mathrm{CO}_{2}$. In the same temperature range, the material crystallizes as orthorhombic $\mathrm{Nb}_{2} \mathrm{O}_{5}$. At higher temperatures, but below $950^{\circ} \mathrm{C}$, the structure is transformed into the monoclinic $\mathrm{Nb}_{2} \mathrm{O}_{5}$.

\section{ACKNOWLEDGEMENTS}

We are grateful to CNPq.

\section{REFERENCES}

Ciaravino, C., Medeiros, F.F.P., Souza, C.P., Satre, P. and Roubin, M., Elaboration of Mixed Tantalum and Niobium Carbides from Tantalite Mineral. J. of Materials Science. 37(10), pp.21172123 (2002).

Clar, E., Ph. D. Diss., Obtention et propriétés de carbures métalliques simples et mixtes à grain fin, Faculté des Sciences de L'Université de Lyon Université Lyon, France (1964). 
Cotton, F.A. and Wilkinson, G., Química Inorgânica, LTC, São Paulo, p.118 (1982).

Khrishnamurty, K.V. and Harris, G.M., The Chemistry of Metal Oxalates Complexes. Chem. Rev, 61, 3, pp. 213-246 (1961).

Marta, L., Zaharescu, M. and Macarovici, C.G., Thermal and Structural Investigation of Some Oxalates-Niobium Complexes 3. Strontium Tris(oxalate)oxoniobate. J. Thermal Analysis, 26, p. 87 (1983).

Marta, L., Zaharescu, M. and Macarovici, C.G., Thermal and Structural Investigation of Some Oxalate-niobium Complexes, Potassium Tris(oxalate)oxoniobate. Revue Roumains de Chimie, 24, 8, p.1115 (1979).
Mathern, G., Weiss R. and Rohmer, R., The Crystal Structures of Ammonium Oxotrioxalatoniobate Monohydrate and Ammonium Diperoxodioxalatoniobate Monohydrate. Chem. Comm., 70 (1969).

Medeiros, F.F.P., Silva, A.G.P. and Souza, C.P., Synthesis of Niobium Carbide at Low Temperature and Its Use in Hardmetal. Powder Technology 126, pp. 155-160 (2002).

Storms, E.K., Refractory Carbides - A Series of Monographs. Vol. II, Academic Press, New York and London, p. 61, 82 (1971).

Toth, L.E., Transition Carbides and Nitrides - A Series of Monographs. Vol. II, Academic Press New York and London, p. 14 (1971). 